\title{
Digital Platform e-Códex: A Hybrid Virtual Space
}

\author{
Márcia Izabel Fugisawa Souza, Tércia Zavaglia Torres, José Ruy Porto de Carvalho, \\ João dos Santos Vila da Silva, Silvio Roberto Medeiros Evangelista, \\ Daniel Rodrigo de Freitas Apolinário
}

\author{
Embrapa Agricultural Informatics, Campinas, Brazil \\ Email: marcia.fugisawa@embrapa.br, tercia.torres@embrapa.br, jose.ruy@embrapa.br, joao.vila@embrapa.br, \\ silvio.evangelista@embrapa.br, daniel.apolinario@embrapa.br
}

\begin{abstract}
How to cite this paper: Souza, M. I. F., Torres, T. Z., de Carvalho, J. R. P., da Silva, J. S. V., Evangelista, S. R. M., \& de Freitas Apolinário, D. R. (2017). Digital Platform e-Códex: A Hybrid Virtual Space. Creative Education, 8, 231-254.

https://doi.org/10.4236/ce.2017.82019
\end{abstract}

Received: December 2, 2016

Accepted: February 17, 2017

Published: February 20, 2017

Copyright (c) 2017 by authors and Scientific Research Publishing Inc. This work is licensed under the Creative Commons Attribution International License (CC BY 4.0).

http://creativecommons.org/licenses/by/4.0/

\begin{abstract}
Mobile learning is the kind of learning that applies mainly to non-formal education actions from the perspective of continuing education. Within the scope of companies, the demand for educational actions is increasing, notably focused on distance education and training, aimed at both internal and external audiences. However, for the implementation of activities dedicated to mobile learning, it is necessary to develop a digital platform to host the virtual learning environment. Under these conditions, it should be structured in a flexible format and design to encourage interactivity between learners and teachers in the implementation of teaching and learning activities. The article presents and discusses a proposal for a digital mobile platform, called e-Códex, which aims to support educational actions, to promote collaboration and learning, as well as to meet the information dissemination and knowledge generation needs of the Brazilian agroforestry sector. The research was carried out in two phases, the first one consisted of a review of the theoreticalconceptual literature on topics involving cyberspace, digital media and education in virtual spaces, in order to subsidize the development of a digital platform for support the educational actions within the scope of the Embrapa Special Forest Code Project. The second phase of the research consisted in the application of questionnaires to the members of the Special Forest Code Project to know their perceptions and interaction requirements, considered relevant in a digital virtual space, in order to favor horizontal and dialogic relations conducive to new learning. The analysis of the data pointed to the definition of essential elements of the platform design, associating with this, a set of functionalities capable of favoring aspects of interactivity, integration, sharing and exchange of information, knowledge and experiences inherent to virtual learning spaces. The e-Códex Platform incorporates aspects considered important by the research subjects, such as: the need for its creation, their main characteristics and contributions, the possibilities of use, and the forms
\end{abstract}


of organization of the contents and activities offered.

\section{Keywords}

Digital Platform, Multimodal Learning, Cyberspace, Virtual Space, Digital Space, Mobile Applications

\section{Introduction}

The increasing incorporation of digital technologies in education, in particular, the non-formal education is associated to the formation and expansion of a new type of learning, the learning mobility, also called mobile learning. For that mobile learning activities occur it is required a digital platform mobile, whose main function is to house an educational environment in the virtual space. This environment is a locus of multi-interactions, as a rule, practiced among learners, teachers and other actors, which are provided with mobile devices (such as mobile phones and tablets) may, at any time and place, share teaching resources and media, information, knowledge, experience etc.

A platform to host a virtual space must be structured in format and design flexible to encourage, especially the aspects of interactivity and interaction involved in implementing activities of teaching and learning. In this way, the construction of a digital platform should be guided by an innovative methodology and a set of technologies capable of favoring the interactivity, the integration, the sharing and exchange of knowledge, and information between the actors involved. Communicational aspects arising from the use of digital technologies should also be considered, since it can provide elements to guide the design of a platform that will meet the needs imposed by the emergence of a new modality of communication, which is set by the interactivity, horizontality, and communicative bidirectionality.

Digital technologies are taken as instruments that facilitate the interactions between people, which coexist in social networks, in an interactive, horizontal and collaborative way. For this reason, they are potentially facilitator of the creation and expansion of opportunities for participation and intervention which arose in the communicational process. Considered as communicational media, these technologies are also highlighted for being carriers of different languages and meanings, revealing a sociocultural character, typical of events such as occur in interpersonal interactions.

Those issues marked the preparation of a proposal for creating a digital mobile platform for housing virtual space that mirror the needs of the target audience for information and knowledge of the implementation of the new Brazilian Forest Code $^{1}$ (Brasil, 2012). That is an important legal framework newly imposed by

${ }^{1}$ Refers to Law no. 12.651, May $25^{\text {th }} 2012$, which provides for the protection of native vegetation and "[...] establishes the general rules about where and how the Brazilian territory can be exploited at determining the areas of native vegetation that should be preserved and which regions are legally entitled to receive the different types of rural production”. (Portal Brasil, 2012: p. 1). 
the Government of Brazil, which aims at the protection of native vegetation, in the environmental and forestry dimensions, throughout the country.

For the implementation of this legislation, public services, such as the Brazilian Agricultural Research Corporation ${ }^{2}$ (Embrapa) were called to contribute with actions directed to the meeting, selection, processing and provision of information about the Forest Code. As the target audience, we can mention the rural producers and entrepreneurs, technicians, extension workers, researchers, students, etc. Within the institutional scope of Embrapa, it is noticeable the lack of virtual environments for the provision of information such as informational multimedia on themes involving the Forest Code.

In addition, regarding the creation of virtual mobile spaces, it is noted the existence of methodological options applied to the production and organization of digital media content, just as there are a variety of tools and technological resources to support the development of software applications in this area.

This context of lack of virtual environments for mobile multimedia at Embrapa, coupled with institutional guidelines for the identification of information technology solutions (IT) appropriate to the adequacy of the rural landscape to the Forest Code, has contributed to the explanation of the research question: what characteristics a digital platform must has to serve as a space of sharing, dissemination of information, collaboration and learning and contribute to the implementation of the Brazilian Forest Code?

Faced with this problem, which is reflected in the lack of a virtual environment to meet the demand of information and knowledge to support the implementation of Brazilian forestry legislation, we proposed the creation of a digital and virtual media platform called e-Códex, using web technologies to the development of applications and solutions for access via mobile devices. The proposal steps were permeated by the search for answers to recurrent questions about the need to organize and provide information and knowledge, such as: A) what methodology should be adopted for creating a digital platform focused on the production and organization of communicational and educational information content, with access via mobile devices? B) What technologies (tools, applications, etc.) should be adopted for creating and structuring this digital platform for access via mobile devices? C) What scope should be defined for the creation of a platform (objectives to be achieved-immersion, agency and engagement in learning; topics/sub-themes to be addressed; competences and skills to be developed, etc.)?

The proposal for a digital mobile platform e-Códex was based on the theoretical framework of hybrid spaces, whose conceptual assumptions foster the development of abilities considered facilitator of the subject interaction in the virtual environment. In turn, the digital technologies used for creating the mobile

${ }^{2}$ Embrapa is a public company linked to the Ministry of Agriculture, Livestock and Food Supply of Brazil, which has the mission of enabling solutions for research, development and innovation for sustainability of agriculture in favor of Brazilian society. The generation of knowledge, the development of technologies and the dissemination of information are the main strategic objectives of Embrapa (Embrapa, 2014). 
platform have been selected taking into account the minimum technical requirements able to promote interaction, collaboration, participation and information sharing, knowledge, experiences, know-how, etc., usually applied to educational and/or communicational digital spaces.

The article is divided into six sections, including this introduction. In Section 2 , the education is discussed under the perspective of digital technologies and multimodal learning ${ }^{3}$, favoring a logical thread for questions and discussions that will be presented in other chapters. Section 3 presents the theoretical aspects that underpin the concepts of space and cyberspace, in particular, the concept of virtual space created for access via mobile devices and locative media, under the perspective of ubiquity, pervasivity, hybridity, and multimodality. In Section 4 we presented the methodology and procedures adopted in the development of the virtual platform proposal. Then, in Section 5 we presented and discussed the results of the survey and the explanation of the proposed digital platform e-Códex. Finally, in Section 6 we presented the conclusions.

\section{Digital Technologies and Multimodal Learning}

Digital technologies have been considered technological devices of vital importance for education because it facilitates the construction of knowledge among students, especially if associated with a theory sociointeractionist (Ayas, 2006). That indicates educational processes that occur through the technologies and digital tools need to be focused on the possibility for people to build the knowledge based on practice, skills, experiences and culture of the collective of people who are part of the situation (Mayes \& Freitas, 2004).

Digital technologies, in particular wireless mobile devices with interactional potential, authorship and collaboration are appropriate to the preparation of projects pedagogical, which aim at helping the apprentice in the construction of knowledge from his own life experience and the context in which it operates (Almeida \& Valente, 2012). In an educational process under such characteristics it is assumed that learning should be made from the interaction that people make between them and the way in which they are entered, as occurs in learning. In this type of learning people are involved in various representations of meaning based in various ways and means of language. The multimodal learning constitutes a challenge for educators who need to create routes of interdependent, complementary, open, and multiple learning, to promote in the apprentices engaging experiences and interactions which allow them to explore situations or concepts through observation or collaborative activities. According to Freitas \& Neumann (2009), the multimodal learning involves learners in different ele-

${ }^{3}$ The term "multimodal learning" derives from the studies of Kress \& Van Leeuwen (2001) and refers to a learning based on a new form of communication, which is a result of the potential of the digital media for bringing meanings through synchronization of modes. These different modes of representing the meanings inherent to each media, contribute so that learning occurs through discovery, exploration and experimentation, being people the main protagonists. The multimodal learning enables various forms of reasoning, especially if the content is produced to take advantage of the affordances of the media, in a complementary and interdisciplinary, as well as if the platform (virtual environment) is structured to support appropriate technology. 
ments of the learning cycle, favoring the transfer of behavior patterns from a context to another.

Multimodal learning approach aligns to the idea of designing a virtual hybrid space, taking it as a potential source of learning in the context of non-formal education. Firstly, because in multimodal learning people can build, share and explore various representations of meanings through narratives essentially shaped to the context of practical situations common to the apprentices. Secondly, in multimodal learning it is possible for apprentices to examine new conceptual trajectories, mobilizing all its resources and cognitive strategies to understand the experience they are experiencing. And finally, the multimodal learning makes clearer the different media in the context of an educational process, not only as channels, but mainly as a means of interaction that promote learning, since they enjoy the best of each one offers (Torres et al., 2015).

\section{Spaces}

Along the civilizing process, humanity has become socially constituted, creating family, grouping into tribes, villages and communities, generating affectional bonds, developing the language, creating instruments and establishing rules for the conduct of peaceful coexistence, anyway, transforming the nature and culture (Backes, 2013). As said by Maffesoli (1996: p. 234), the nature "is no longer considered simply as an object to be exploited, but it is increasingly a partnership process".

Through the work, mankind, in his transforming role of nature, gave rise to the creation of instruments, originally designed for fishing and hunting, which with the passing of time were also used as weapons. At all times, both the instruments as the techniques ${ }^{4}$ bring engendered the respect that man establishes with the nature, resulting in the creation of the material conditions for human existence, as well as in the construction of their spaces of coexistence. Thus, since its origin, the mankind follows transforming the reality through the development of tools and techniques, promoting leap of evolution, since the creation of simple utensils for survival, in the early days, to the sophisticated information and communication technology (ICT), in the present day.

Space is a term that encompasses many concepts, which are bound to different areas of knowledge, such as mathematics, cosmology, philosophy, geometry, physics, statistical mechanics and practice, physical mechanics etc. Nowadays, other spaces are created, directed to the perception and the human experiences, and in this perspective, "[...] Space start to have a psychic statute, social and historical that presents an overflowing multiplicity of facets" (Santaella, 2011a: p. 164). Thus, in this space of so-called human experience, are included the primi-

${ }^{4}$ The word technique often mentioned in this text should be understood according to the precepts of Santaella (2010: pp. 152-153), which affirm: "While the technique is a know-how, whose intellectual nature is characterized by skills that are introjected by an individual, technology includes the technique, but goes beyond it. There is technology wherever a device, appliance or machine is capable of incarnating, outside the human body, a technical knowledge, a scientific knowledge about specific technical skills". 
tive space, the perceptual space and the space of existence

\subsection{Cyberspace}

The intense technological change led in the last two centuries shook profoundly the traditional spaces of human existence, causing significant changes toward the constitution of new spaces of experience. Derived from this context of accelerated social changes and technological innovations, the spaces of communication appear, especially the media communication. As point out by Santaella (2011a: p. 177), this is "[...] a type of space that is not separated from the living, but it weaves. [...] the space created by the networks-the virtual space, global, multidimensional, supported and accessed by computers-came to be called 'cyberspace', a term created by William Gibson in his novel Neuromancer, in 1984 ”.

The cyberspace is also defined as an electronic communication system which brings together the humans and computers, in a symbiotic relationship that grows exponentially in an interactive way. It is also designed as any informational space of interaction with the human being, by means of access, handling, processing and interchange of information. In it the communication is convergent, global, planetary. The cyberspace or the network-which is comprised of countless sub-networks-is an open and freedom space, formed by informational circuits infinitely navigable, since the regulatory mechanisms of the capitalist market are respected (Santaella, 2011b). In this sense, cyberspace must be understood not only as a simple consequence of technological progress, but also as a new array of political, economic and cultural rights engendered by the information revolution (Santaella, 2010).

In a not naive vision of the cyberspace, the semiotician Lucia Santaella states:

Finally, far from emerging as a kingdom somehow innocent, the cyberspace and its virtual experiences are being produced by contemporary capitalism and it is necessarily impregnated of cultural forms and paradigms that are peculiar to the global capitalism. The cyberspace, therefore, is far from inaugurating a new emancipating era. Although the internet is revolutionizing the way we live, it is a revolution in which nothing changes the identity and nature of the amount each time more exclusive and a reserved of those who hold the wealth and stay in charge. (Santaella, 2010: p. 75).

Under another dimension, the access to cyberspace by people who surf on the virtual spaces is done via mobile devices, i.e., cell phones and tablets, considered the main instruments of communication and interaction. As the same way, the locative media ${ }^{5}$ are endowed with technical elements capable of exerting influence on the reconfiguration of virtual and physical spaces and to promote the construction of narratives, allowing combinations of aspects of the technique, the space and the narrative, with impacts of one over the other.

${ }^{5}$ Locative media is a term coined by Karlis Kalnis, from the Center for New Media, Riga, Latvia, in 2003. According to Lemos (2007: p. 1), locative media are processes of emission and reception of information from a specific place, which implies a relationship between places and mobile devices. 
Mobile communications devices reinvent urban spaces such as multi-users connected regardless of geographical position and physical presence, favoring the emergence of hybrid spaces, i.e., defined by the disappearance of borders between physical and virtual and created by the constant mobility of users who use mobile devices (Caetano Nêto, 2011: p. 1).

The mobile devices represent the technique because they result from production processes based on the increase and development of technique and technology. In addition, we use and deal with sociotechnical spaces for construction of new narratives. According to Backes (2007, 2011, 2013), digital technologies, among which include mobile devices, are also understood as virtual and digital spaces, because "[...] allow the action, relation, interaction and sharing of representations of human beings [...]" (Backes, 2013: p. 4).

In this sense, new virtual spaces are liable to be created, thanks to hybrid character of digital technologies, which consists of crosses, integration and articulation of different technological gadgets and artifacts (digital media), in view of the existence of relations between human and no-human actors.

Next, concepts as ubiquitous, pervasivity, hybridism and multimodality are briefly presented. They are considered elements which characterize the cyberspace and, therefore, essential in the configuration and creation of any virtual spaces, as it is the e-Códex.

\subsection{Ubiquity and Pervasivity in Virtual Spaces}

In the perspective of geographical studies, the configuration of space is defined by Santos (1980: p. 122) "[...] as a set of shapes representing social relations of past and future [...]. The space is, then, a true field of forces whose acceleration is unequal. That is the reason why the space evolution is not identical across all places".

Ubiquity and pervasivity are "[...] basic premises for a new configuration of urban space, where wireless technologies are popularized in order to generate a pattern of nomadic life" (Caetano Nêto, 2011: p. 1). Ubiquity is defined as the property or condition of what ubiquitous is, what it means, the ability to be in several places at the same time. For its turn, pervasivity is a term that refers to the pervasive computing, in which "[...] the technologies dissipate in the day by day stuffs until they become indistinguishable [...]" (Caetano Nêto, 2009: p. 32), providing access all the time, anywhere, and whenever you want.

Pervasivity brings imbricate the concept of locative media, which are defined by Lemos (2007: p. 1), as "[...] a set of technologies and info-communicational processes whose informational content links to a specific place". The locative media are, therefore, technologies responsible both for issuing and receiving information from one location, using mobile devices that process data and information, generating analysis and adding them to this place.

The use of mobile devices, particularly associated to locative media directly corresponds with technological development, which continuously introduces changes in how society organizes itself, faking the appearance of new concepts about the relationship between space, time and city, especially. New social con- 
figurations based on the relations between these elements "[...] significantly change our way of living, thinking and consume information" (Caetano Nêto, 2011: p. 3).

There are many examples of application of pervasive computing aimed at creating virtual spaces, using mobile technologies, and that bring new settings in order to live, to think and to consume information. In this way, it seems appropriate to introduce here a brief discussion about the hybridity and multimodality in virtual spaces, under the perspective of the intrinsic mobility referring to mobile devices.

\subsection{Hybridism and Multimodality in Virtual Spaces}

The term hybridity has its origin in biology, being normally used to refer to a hybrid character of genetic species originating from different species (Canclini, 2006). Meanwhile, hybridity is a phenomenon that extends to other areas of knowledge, as the language. In this field, hybridity is attributed to the formation of words through the junction of radicals belonging to different languages, as is the case of "automobile", whose radical "auto" has Greek origin, and the radical "mobile" Latin origin.

Based in Latour (1994), Caetano Nêto (2009: p. 44) says that hybrid "[...] is a term easily used with the aim of providing a quality less 'pure' or unilateral to things". From Latour's conception it is understood that hybrid is a phenomenon that is by multiple arrays and mixtures of nature and culture, from interactions that occur inextricably between actors human and non-human.

Hybridity is also presence in the media, above all, from the first decade of the 21 st century, when we see a fast incorporation of mobile communication devices in both physical and virtual environments. In terms of evolution, this phase corresponds to the fifth generation of the communicational technologies, in which we witness the fast incorporation and symbiosis of mobile devices in communication. The antecedent phases, briefly, are: the means of mass communication (first generation); the electro electronics (second generation); the appliances, devices and processes of communication narrow casting (third generation); the personal computers linked to information technology networks (fourth generation) (Santaella, 2011a).

As a result, it appeared that hybridity also articulates and integrates the field of digital technologies, coming to form what is called a digital and virtual hybridity. In other words, this junction is "[...] a coherent set of possibilities of realization of the human action in a space of virtual digital nature, by means of digital technologies" (Backes, 2013: p. 8).

Thus, in a context of hybridity, the interaction and communication flow in an articulated manner so that each virtual digital media and/or space perform their functions, using different languages (text, audio, visual, gestural) or mixtures and combinations between them, i.e., of languages and hybrid transmedia (Santaella, 2009; Torres et al., 2015). Following Santaella (2010), the main bases of digital hybridity remain in the convergence of media, formerly separated, and in relation prompting between the human being and the text and/or hybrid 
space. And nothing better to describe contemporary culture than the concept of hybrid, which according to Santaella (2011b: p. 132) underlies "[...] the mixtures between the media, under the name of multimedia, and for mixtures between systems of signs, various and different languages configured in hypertextual structures, under the name of hypermedia".

It is conceived, thus the digital spaces such as stages of actions and interactions that are established between human and non-human actors, including mobile devices, forming relationships that are inseparable and networks that connect to nature, technique and culture. Naturally, in times of predominance of social networks, interactions ${ }^{6}$ in digital spaces have evolved from monomodality to multimodality, making it necessary to briefly comment this transition.

A characterization of the monomodal interaction is given by Santaella (2010), by employing the metaphor of surfing and browsing time-thus the timelessness of cyberspace-which presupposes a beginning and an end, corresponding to the phase of organization of information from the constitution of files and repositories for access in accordance with dates and times previously established. This phase corresponds to the beginning of the interactions in the network (1990), and is referred to as monomodality, according to its character and unidirectional nature of its journey, which is always the same, and yet, the type of access that occurs by means of fixed points in the dimension of time and space. In the monomodal phase it is common to associate the digital navigation on the network to a course similar to "[...] a huge maze, where we need to find many streets without exit before we meet our goal" (Santaella \& Lemos, 2010: p. 56).

The monomodal interaction occurred at the beginning in the late 1990s follows its evolutive course, opening passage to the multimodal interaction, which consolidates itself as from 2009, with the emergence of Twitter in social networks 2.0. Thus, in multimodal phase the advances in digital communications are significant, as the incorporation of functionalities in the same interface, such as: exchange of messages between members of the discussion group, collective messages, comments, forums, chats, collective framework of errands, collective repository of documents etc. In other words, in this phase of transition to multimodality there was the incorporation of multiple features of interaction of monomodal type, which became part of the same platform (Santaella \& Lemos, 2010).

A differentiating element of interaction in multimodal refers to mobility introduced with the hybridization of applications, spaces and digital technologies, such as mobile devices, particularly mobile phones and tablets, greatly expanding the possibilities for access of people to content and virtual environments, regardless of place and time.

In this way, it would be unthinkable to design the construction of a digital platform, such as the e-Códex, disregarding the elements discussed previously, such as: ubiquity, pervasivity, hybridity, and multimodality. In addition, these elements also refer to the implementation of teaching and learning activities in ${ }^{6}$ Santaella and Lemos (2010) suggest two types of interaction characterizers of virtual spaces: monomodal interaction and multimodal interaction, which represent distinct stages of evolution social networks (RSIs). 
virtual environments. These are essential questions that will be in the proposal for e-Códex platform presented and discussed on chapter five.

\section{Methodology}

This is a survey of exploratory and descriptive and qualitative approach, developed at Embrapa Agricultural Informatics ${ }^{7}$, under the Special Project Forest Code $^{8}$, aiming at the construction of a digital space to share and disseminate informational content, to promote collaboration and learning. The research was carried out in two phases. The qualitative phase has as main objective the identification, from a review of the literature of some theoretical and conceptual constructs, in topics that involve the cyberspace, the digital media and education in virtual spaces, in order to subsidize the development of a digital platform to support the actions relating to the Special Project Forest Code of Embrapa. The phase of research had as main objective to identify, along with members of the Special Project Forest Code the perceptions and the requirements of interaction in a digital virtual space, in order to favour a horizontal and dialogic relationship, conducive to new learnings.

The collection of data from the qualitative phase followed the steps described in Figure 1. In this Figure 1, the three phases involved in data collection are represented as "Input", which concerns of the problems and goals, primary sources, search strings and qualification criteria; "Processing" which consists of the realization of searches, analysis of results and documentation; "Output" which includes of the register and data storage, synthesis of results and elaboration of the theoretical constructs.

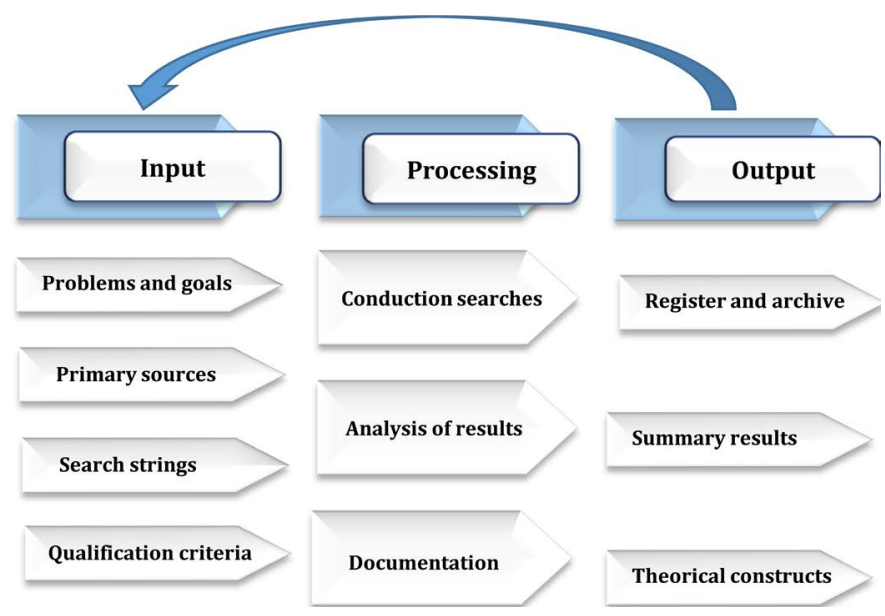

Source: Adapted by of Conforto et al. (2011).

Figure 1. Model of systematic literature review.

${ }^{7}$ Embrapa Agricultural Informatics is a unit of research in information technology applied to agriculture in the areas of software systems engineering, scientific computing, communications technology, bioinformatics and agroclimatology (Embrapa Agricultural Informatics, 2016). It has institutional mission to provide solutions for research, development and innovation in information technology for the sustainability of agriculture in favor of Brazilian society (Embrapa, 2011).

${ }^{8}$ Forest Code Project is the special project of Embrapa, called Technological Solutions for Adequacy of the Rural Landscape to the Brazilian Forest Code, which includes, among others, the line of research "Provision of Information Technology Tools to Assist in Adequacy to the Brazilian Forest Code". 
Once adjusted the criteria established in entry phase, the procedure have been adopted for the implementation of the processing phase: a) search in databases and periodicals; (b) Selection of reading of the collected material (1st selection consisted of the identification of title, abstract and keywords; 2nd selection consisted in reading the introduction and the conclusion of the selected documents by title, abstract and keywords; 3rd selection corresponded to the complete reading of selected documents in the second phase: reading of the introduction and conclusion); c) synthesis and results abstracted from the complete reading of the documents. The third phase consisted of identifying the theoretical constructs that were abstracted from the registry held at the stage of processing and contents of these records.

To perform the data collection in phase of research, it was developed a multiple choice questionnaire ${ }^{9}$, of type Likert scale (Bozal, 2006). The questionnaire was applied online to 123 people, members of the Special Project Forest Code. There was no information about the subject's profile characterization. From 123 people who composed the research universe, we obtained the answer of 61 people ( $49.5 \%$ of the universe). This questionnaire used as a basis the constructs abstracted in the qualitative phase of the study, referring the characteristics that should guide the design of a digital platform, whose goal is to foster collaboration, sharing, dissemination and learning.

Four important constructs that guide the development of a digital platform were defined. The first, called generic construct, seeks to understand how much the research subjects consider important to create a digital platform to disseminate information, promote collaboration and learning about issues inherent to the Forest Code and the degree of importance they attach to it.

The second construct refers to the characteristics that a platform of sharing/dissemination, collaboration and learning must have to fulfill its objectives and the degree of contribution that such characteristics could provide to the subjects that access.

The third construct is linked to the use of the platform, i.e., identifies whether the subjects who would access the platform, would do it for sharing/dissemination of information, cooperation with partners in discussions on the theme or for learning/achievement of knowledge.

The fourth construct is on how they the contents and the activities should be arranged on the platform.

The quantitative data were processed through the analysis of correspondence which is a multivariate technique for exploratory analysis of categorized data (Carvalho et al., 2002). The technique of correspondence analysis converts an array of non-negative data in a particular type of chart/map that allows us to visualize "[...] the proximity/distance and the relationships between rows and columns (stimuli) of a contingency table (usually also called cross table, crossing, crosstab), in two or more dimensions" (Cunha Jr., 2000: p. 34). This enables the relationship between the lines between the columns and rows and columns can

${ }^{9}$ Questionnaire created using Google Forms, available in https://goo.gl/JL81IK 
be interpreted. This technique was chosen because, besides being more appropriate for the type of data collected in this survey of descriptive nature, it also promotes the versatility in the treatment of categorical variables and makes it easier the implementation and interpretation of the results.

\section{Results and Discussion}

\subsection{Presentation and Data Analysis}

Data analysis was preceded by the use of graphs to visualize the relationships between the variables. At representing a set of points, the absolute frequencies of each line were not observed, but the profile of a line along the categories of the columns. At introducing the profiles, the points were standardized, thus reducing the information to according to the individuals in each line (Carvalho et al., 2002).

For obtaining the axes, we observed the accumulated percentage of main inertias and, based on the percentage explained by inertia, we calculated the number of axes required for the representation of points (Table 1) (SAS Institute Inc., 2008). As can be seen in this context, the total of the statistic chi-square test is 846.67, which is a measure of association between the rows and columns in all dimensions of the data table transformed, obtained by the decomposition of natural values. About $29 \%$ of the statistic chi-square test and inertia is explained by the first vectorial axis, while about $20 \%$ is explained by the second vectorial axis (as can be seen in the chart to the right of the table). In this study, the points were represented in two axes, indicating that the association between rows

Table 1. Decomposition of inertia and chi-square test. Analysis of correspondence for the variables.

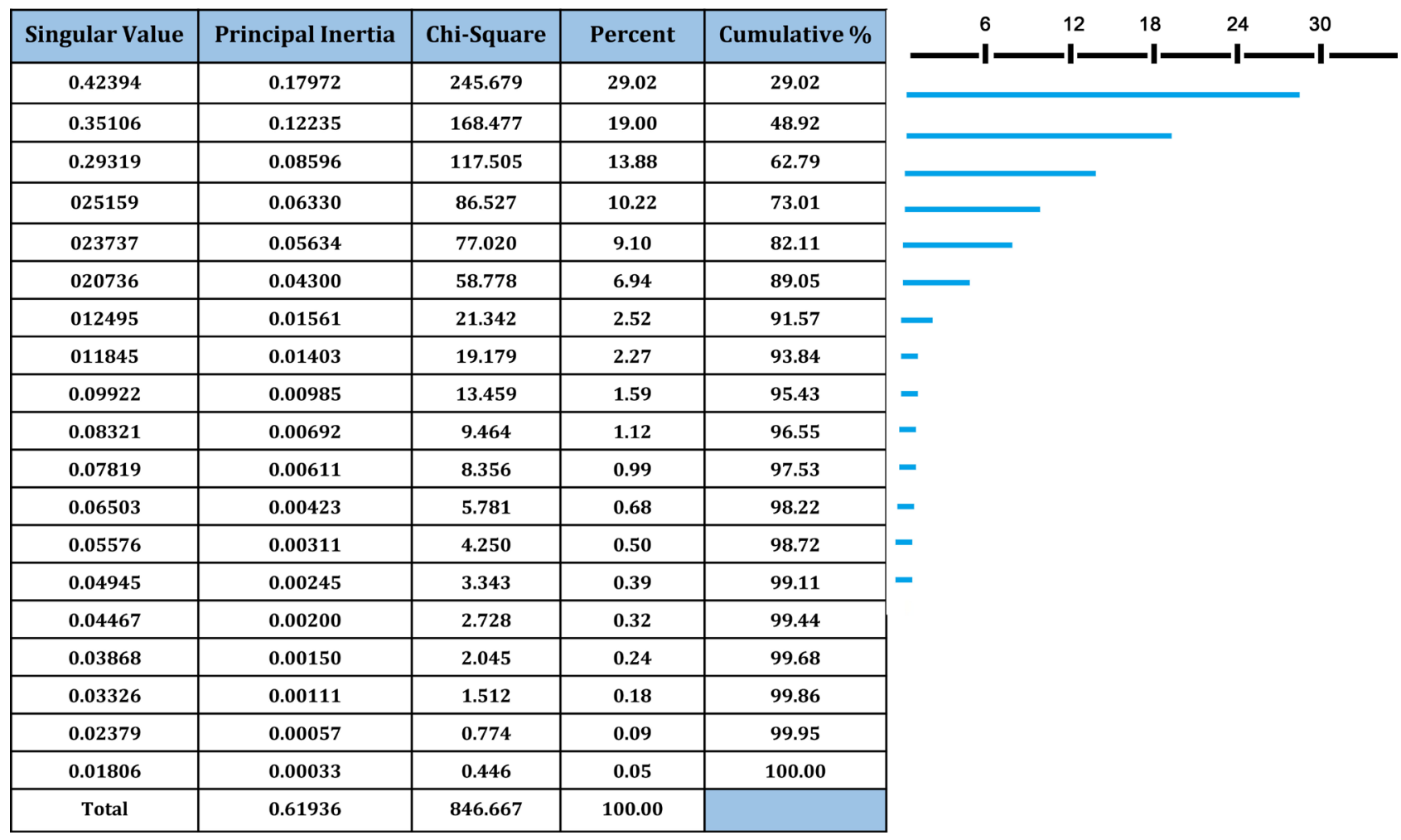


and two-dimensional columns, with $49 \%$ of the inertia explained. As the other dimensions were smaller, there was no loss of information when only two dimensions were considered.

In the interpretation of the axes, it was found that the inertia of the points decomposes itself on each axis. The components of the inertia form the coefficients that indicate how much each point contributed to determinate the direction of the axes and how much each item is represented in each axis indicated by the coefficients $\mathrm{C} 1$ and $\mathrm{C} 2$, as seen in Table 2 below.

Table 2 displays the coordinates of the variables for the two axes and their

Table 2. Summary of statistics for the variables of the study. Analysis of simple correspondence.

\begin{tabular}{|c|c|c|c|c|c|c|c|c|}
\hline Obs & Name & Axis 1 & Axis 2 & C 1 & C 2 & QR 1 & QR 2 & Best \\
\hline 1 & q1 & -0.20786 & -0.01526 & 0.00756 & 0.00006 & 0.40657 & 0.00219 & 1 \\
\hline 2 & q2 & -0.19344 & -0.10015 & 0.00975 & 0.00381 & 0.26333 & 0.07059 & 1 \\
\hline 3 & q3a & -0.18908 & -0.00240 & 0.00611 & 0.00000 & 0.34305 & 0.00006 & 1 \\
\hline 4 & q3b & -0.19256 & -0.00482 & 0.00604 & 0.00001 & 0.20569 & 0.00013 & 1 \\
\hline 5 & q3c & -0.18782 & -0.04389 & 0.00574 & 0.00046 & 0.20467 & 0.01118 & 1 \\
\hline 6 & q4a & -0.17549 & -0.10569 & 0.00489 & 0.00259 & 0.14706 & 0.05334 & 1 \\
\hline 7 & q4b & -0.16225 & -0.02103 & 0.00793 & 0.00019 & 0.09061 & 0.00152 & 1 \\
\hline 8 & q4c & -0.18561 & -0.07061 & 0.01641 & 0.00346 & 0.17544 & 0.02539 & 1 \\
\hline 9 & q4d & -0.13761 & 0.13029 & 0.00863 & 0.01129 & 0.04022 & 0.03605 & 2 \\
\hline 10 & q4e & 0.29580 & -0.38101 & 0.03205 & 0.07755 & 0.07142 & 0.11850 & 2 \\
\hline 11 & q4f & 2.46496 & 0.90804 & 0.29678 & 0.05873 & 0.53095 & 0.07205 & 1 \\
\hline 12 & q4g & -0.03304 & -0.11913 & 0.00096 & 0.01828 & 0.00355 & 0.04612 & 2 \\
\hline 13 & q4h & 1.47169 & -0.31301 & 0.56422 & 0.03722 & 0.78177 & 0.03536 & 1 \\
\hline 14 & q5 & -0.19393 & -0.07619 & 0.00934 & 0.00210 & 0.19680 & 0.03037 & 1 \\
\hline 15 & q6a & -0.22689 & -0.14507 & 0.01173 & 0.00700 & 0.20164 & 0.08244 & 1 \\
\hline 16 & q6b & -0.13716 & -0.15191 & 0.00475 & 0.00849 & 0.15162 & 0.18597 & 2 \\
\hline 17 & q6c & -0.11051 & -0.23292 & 0.00204 & 0.01320 & 0.02868 & 0.12740 & 2 \\
\hline 18 & q6d & -0.05884 & -0.04505 & 0.00066 & 0.00057 & 0.01223 & 0.00717 & 1 \\
\hline 19 & q6e & 0.12376 & -0.03556 & 0.00349 & 0.00042 & 0.07208 & 0.00595 & 1 \\
\hline
\end{tabular}

Legend of variables:

q1 - The importance of the creation of the digital space.

q2 - Degree of importance attributed to the digital space of the Forest Code Project.

q3a - Use of space to learn/gain knowledge from interactions with other people.

$\mathrm{q} 3 \mathrm{~b}$ - Use of space to collaborate with other people in discussions about the Forest Code.

$\mathrm{q} 3 \mathrm{c}$ - Use of space to share/disseminate information.

$\mathrm{q} 4 \mathrm{a}$ - Characteristics of interactivity: notification of reports, journalistic materials, statements and/or other texts related to themes inherent to the Forest Code.

q4b - Interactivity characteristics: invitations to events (fairs, workshops, seminars, congresses, field days, lectures, etc.) related to themes inherent to the Forest Code.

$\mathrm{q} 4 \mathrm{c}$ - Interactivity characteristics: repositories of multimedia resources (videos, slides, infographics, photos, podcasts, etc.) related to themes inherent to the Forest Code.

q4d - Interactivity characteristics: interaction space (blog, forum, comments, chat, twitter) with members of e-Códex.

$\mathrm{q} 4 \mathrm{e}$ - Interactivity characteristics: open access space to know the profile and electronic address of the members.

$\mathrm{q} 4 \mathrm{f}$ - Interactivity characteristics: space to schedule appointments.

q4g - Interactivity characteristics: distance learning courses.

$\mathrm{q} 4 \mathrm{~h}$ - Interactivity characteristics: access to social networks.

q5 - Contribution of the characteristics to favor the sharing/dissemination of information, collaboration and learning between people.

q6a - Organization of contents and activities to promote the synthesis of essential concepts.

$\mathrm{q} 6 \mathrm{~b}$ - Organization of contents and activities in a clear, direct and simple way.

$\mathrm{q} 6 \mathrm{c}$ - Organization of contents and activities to attract my attention (colors, movements and other stimuli) to facilitate my assimilation.

q6d - Organization of contents and activities to explore new contents and information to complement the subject presented.

q6e - Organization of contents and activities to enable the exchange of information with colleagues who participate in the digital space. 
contributions and quality of representation: the variables q1, q2, q3a, q3b, q3c, q4a, q4b, q4c, q4f, q4h, q5, q6a, q6d and q6e show greater contribution to the first axis, while the variables $\mathrm{q} 4 \mathrm{~d}, \mathrm{q} 4 \mathrm{e}, \mathrm{q} 4 \mathrm{~g}, \mathrm{q} 6 \mathrm{~b}$ and $\mathrm{q} 6 \mathrm{c}$ for the second axis (Figure 2).

In the same table, the quality of its representation, indicated by the coefficients QR1 and QR2, can also be seen. The quality of representation is the coefficient that indicates how much each point is, or is not, well represented in the considered subspace.

How the correspondence analysis allocates points in a Euclidean space, the projections of the points on the axes us to draw conclusions about their similarities or dissimilarities. The results from Table 1 and Table 2 allow the generation and interpretation of Figure 2, defined by the coordinates of the first two vectorial axes.

The combination of the results obtained in the qualitative phase of the study (theoretical constructs) with the results of the interpretation of variables similarity contained in the Figure 2 allow the analysis that follow in section 5.2 below. As the first axis of Figure 2 has contributed with 29\% of the explanation of chi-square and inertia, the variables which are in this axis will be the ones analyzed in each of the theoretical constructs.

\subsection{Presentation of the Results}

\subsubsection{Importance of e-Códex Platform}

Nowadays, companies seek to expand its capacity for technological innovation, in a manner of producing new products and introducing constant improvements in the production process to ensure greater flexibility, productivity and competitive advantage.

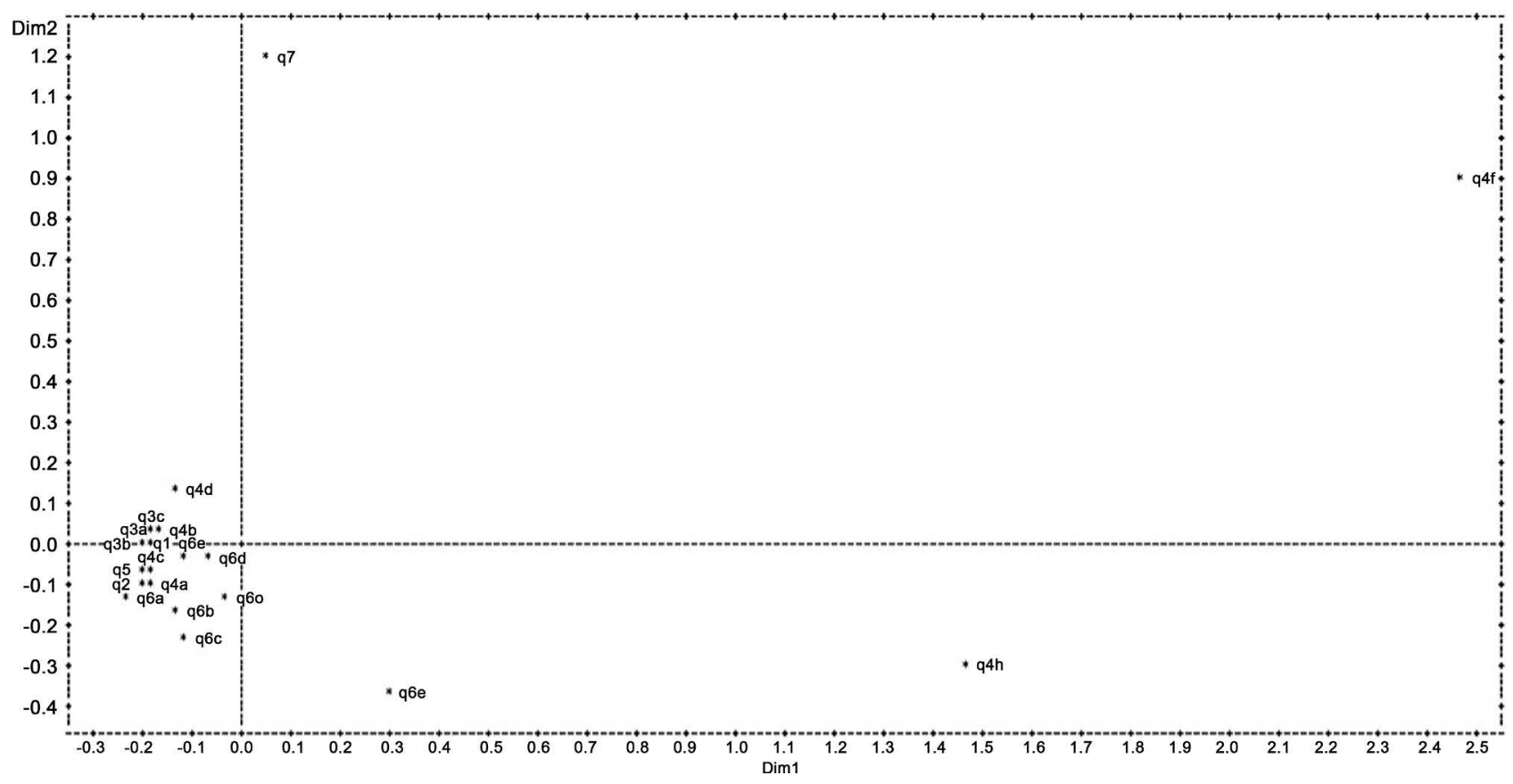

Figure 2. Map of simple correspondence with the variables defined in Table 2. 
There is, in the organizational sphere, the recognition that information and knowledge are one of the forms of companies to promote innovation. In this sense, they have make efforts to intensify the use of digital technologies to form, empower and/or qualify people in order to promote a horizontal communication and dialog with the stakeholders (Lastres, 1994; Kuhlen, 2003). The portability of the technological artifacts of communication, combined with the ubiquitous expression and the aspect of connectivity, enhances the ability of people to produce, consume and spread more information (Sheller \& Urry, 2006; Lemos, 2007).

The understanding of the perception of research subjects about the importance of a digital platform for Embrapa is one of the first steps to start its construction. In this sense, the variables $\mathrm{q} 1$ and $\mathrm{q} 2$ have measured that the research subjects admit it is important to build virtual spaces in the company.

This result corroborates the opinion of specialists (Primo, 2003; Rebollo-Catalán \& Vico-Bosch, 2014), who consider the current ICT as a means of promoting new relationships between people, making them interacting. For Embrapa, this result means a signal for the necessary construction of a collective space for collaborative participation, destined to the exchange of information and knowledge and learning between members of this environment. Recuero (2000) points out that virtual environments, as e-Códex, are the consequence of the interaction between the human and the cyberspace because they are structured by the common interest of its members who adopt a communicative interaction as the primary means to form social groups which, although they have as its starting point the virtual space, extend beyond it.

\subsubsection{Characteristics and Contributions of the e-Códex Platform}

Nowadays, there is a kind of bidirectional dynamic communication enhanced by digital virtual tools, among which stands out the Facebook, Wikipedia, Twitter, virtual communities etc. Digital platforms based on principles of design contribute to enlarge the possibilities of information sharing, collaboration and collective action of people (da Silva, 2010; Mattar, 2011; Spagnoletti et al., 2015).

e-Códex is one of the platforms that can be understood as a 'virtual community', since its main focus is human interaction, perceived as a whole organic, i.e., an environment in which people exert a synchronous communication, whose relations are sustained by affectional bonds and union (Tönnies, 1955). In accordance with Gawer (2009), quoted by Spagnoletti et al. (2015: p. 364), digital platforms are configured as "[...] the building block that provides an essential function to the technological system and serves as the foundation upon which complementary products, technologies, or services can be developed."

One of the main characteristics of digital platforms, according to Baldwin \& Woodard (2008: p. 7), is the existence of "[...] certain components remain fixed over the life of the platform, while others are allowed to vary in cross-section or change over time. Thus either by design or simply because it is the longest-lived component in the system, the platform embodies a set of stable constraints, or design rules, that govern the relationships among components". 
In this sense, Spagnoletti et al. (2015: p. 4) affirm that "the digital platform exhibits the layered modular architecture in which elementary IT capabilities are grouped into software applications that are combined to satisfy generic functional specifications that meet the needs of multiple, de and growing user communities".

Considering the technological advances in the area of IT, virtual environments such as e-Códex must follow this logic, and mainly rely on an architecture design of innovative platform and capable of structuring social interaction in order to provide, by means of a communication, dialogical and horizontal, information sharing, collaboration, collective action and mutual learning between people.

For the research subjects, the structure of interaction that the platform e-Códex should adopt so that be favored the relations between people is enshrined in the variables $\mathrm{q} 4 \mathrm{a}, \mathrm{q} 4 \mathrm{~b}, \mathrm{q} 4 \mathrm{c}, \mathrm{q} 4 \mathrm{f}, \mathrm{q} 4 \mathrm{~h}$ and $\mathrm{q} 5$, representing degree of similarity of $29 \%$, as observed in the first vectorial axis of Figure 2. Table 3 shows each of the variables with their respective degrees of contribution.

The responses of the subjects showed that the construction of a platform with the objective of e-Códex should have as central point a structure of social interaction. This means opting for a technological design of environment which fosters in the interactors the information sharing, exchanging ideas and knowledge, the development of collaborative work and collectives of common interests. Spagnoletti et al. (2015) argue that the design of a digital platform should be appropriate to the interests for which the environment has been created. In this sense, the design of the platform runs through the construction of conceptual architectures and technology aligned with each other. These authors propose three sets of interaction to be covered by digital platforms: information sharing, collaboration and collective action.

In the interaction of the type "information sharing", the platform must offer technologies that promote and strengthen volunteer actions between the interactors who access it, giving them freedom of definition about what should or

Table 3. Platform characteristics.

\begin{tabular}{|c|c|c|}
\hline $\mathrm{N}^{\bullet}$ of variable & Variable description & Contribution \\
\hline $\mathrm{q} 4 \mathrm{a}$ & $\begin{array}{l}\text { Notifications of news reports, stories, testimonies and/or } \\
\text { other texts related to themes inherent to the Forest Code. }\end{array}$ & 0.00489 \\
\hline $\mathrm{q} 4 \mathrm{~b}$ & $\begin{array}{l}\text { Invitations to events such as fairs, workshops, seminars, } \\
\text { conferences, field day, lectures etc.) related to issues inherent } \\
\text { to the Forest Code. }\end{array}$ & 0.00793 \\
\hline $\mathrm{q} 4 \mathrm{c}$ & $\begin{array}{l}\text { Repositories of multimedia resources (videos, slides, } \\
\text { infographics, photos, podcasts etc.) related to issues inherent } \\
\text { to the Forest Code. }\end{array}$ & 0.01641 \\
\hline q4f & Space for commitments schedule. & 0.29678 \\
\hline $\mathrm{q} 4 \mathrm{~h}$ & Access to social networks & 0.56422 \\
\hline q5 & $\begin{array}{l}\text { Contribution of characteristics for facilitating the } \\
\text { sharing/dissemination, collaboration and learning. }\end{array}$ & 0.00934 \\
\hline
\end{tabular}


should not be made available on the platform. In the interaction of the type "collaboration", the digital tools to be implemented on platform should allow that the sharing of information be directed to common objectives. Thus, the design of the platform should contemplate the possibility of the managers of the platform to coordinate the actions performed by the interactor, because in collaboration, people exchange experiences, discuss collective actions and learn from each other, what requires a work of coordination, monitoring and verifying of what was executed by members of the community. The interaction of the type collective action is an interaction more complex that will require technological tools that emphasize the broad participation, involvement and commitment of the interactors who access the platform. The interaction of the type "collective action" is installed when people have already established bonds of trust with each other and are willing to explore more clearly its rationality and ideologies. It is what happens in virtual platforms adopted by social movements, political parties and governments, whose interests are more focused on the promotion of collective and consensual actions.

\subsubsection{Use of the e-Códex Platform}

In institutions for research, development and innovation (PD\&I), as Embrapa, the creation of digital platforms is seen beyond a jumble of technological artifacts, but, as a space of intelligence that contains an important substrate for reflection on themes of common interest (Alves, 2014), which serve to leverage the creation and dissemination of knowledge.

At Embrapa this understanding has been guiding the definition of strategies to promote the area of PD\&I. Among the strategies we can mention the construction of technological tools to boost innovation and the transfer of information and technology; create, maintain and expand streams, canals and formal spaces and informal dialog and reciprocal influence between the public affairs of the institution; strengthen the strategic intelligence organizational and establish a policy of participatory management. This company's interests necessarily passes through the establishment of communication channels of dynamic character, based in collaborative premise, able to offer, on the one hand, greater adherence to its mission and institutional objectives and, on the other hand, the possibility of promoting/increase the generation and dissemination of new knowledge, knowledge, experiences and learning among researchers.

The e-Códex is, therefore, one of those channels of communication designed to support the construction, storage and dissemination of information and knowledge pro-produced by Embrapa, i.e., a locus of interaction and collaboration between researchers and their target audiences, internal and external. According to Evers (2002) and Jones (2001), environments of this nature are more than necessary because the knowledge, raw material of the institutions of PD\&I, is fed with knowledge. The existence of a space for sharing, stimulates and handle the exchange of ideas, suggestions, experiences, knowledge and know-how between people, serving as an instrument of potentiating learning individual and collective housing (Nonaka \& Konno, 1998; Choo, 1996; Alvarenga Neto \& Bar- 
bosa, 2007).

The points highlighted by the literature about the use of digital platforms in institutions PD\&I are reinforced by the perception of research subjects, as shown in the variables with degree of similarity of $29 \%$, indicated in the first axis of the chart. The subjects of the research indicated that the e-Códex should primarily be used to: a) to learn/get knowledge from interaction with other people; b) to collaborate with others in discussions about the Forest Code; c) to share/disseminate information.

\subsubsection{Form of Contents Organization and Activities on e-Códex Platform} Virtual communities as the e-Códex require the intentional organization of contents e activities to promote the achievement of the objectives for what it was created to (Torres \& Amaral, 2011). They require, as already discussed, a design of technological platform that fosters relationships between the main and a dialogical communication, horizontal and interactive that prioritizes the reciprocity in relationships.

One of the main functions of the virtual community is to propel the learning between people. To do this, you must contemplate the necessary resources and organize the processes that allow people to interact with each other and learn from each other, considering the issues and common interests. Virtual communities should provide their members sharing information and collaborative learning, which is why it has been one of the favorite options of interaction by the institutions of PD\&I, that consider them as "carriers of winds of change, of expectations of innovation, hopes of improvement" (Coll et al., 2010: p. 269) and learning.

It is in interaction with each other and with the means, according to the Vygotsky's conception, that the learning occurs. To learn is to build senses and meanings from the polyphonic dialog produced by the presence of several voices in the discourse (Castro \& Ribeiro, 2010). The basis of virtual communities is the dialog and this is present in the act of communication that, by context, is the source of learning (Martin \& Parker, 2014). Therefore, it is necessary to plan the technical conditions that the platform will offer to the interactors in a way which allows that those three elements be convergent, harmonized and integrated into the community e-Códex, from the perception signed by the research subjects.

The data collected in this survey pointed to three variables (q6a, q6d and q6e), which refer to forms of organization of contents and activities on the platform and belong to the first axis of Figure 2, whose degree of similarity is $29 \%$. The variable q6a refers to the organization of contents and activities in e-Códex, in order to offer a summary of key information about the Brazilian Forest Code to interactor in the community. The variable q6d indicates the need of the platform e-Códex allow the interactor explore new information, aiming at interdisciplinary complement between different sources of information. Finally, the variable q6and reflects the importance that the e-Códex should assign to the aspirations of the interactors to carry out information exchanges, knowledge, and know-how. 


\section{3. e-Códex Digital Platform for Mobile Applications}

The development of the platform e-Códex to house the virtual mobile space, in relation to the aspects of information technology (IT), was based on basic premises for setting up digital spaces, virtual as the ubiquity, pervasivity, hybridity, and multimodality, previously discussed.

With regard to the aspects of design, the construction of space e-Códex was based on the people's perception collected from the target audience of a virtual environment for carry out experiences of sharing, dissemination, collaboration and learning, under the scope of the Project Forest Code.

Thus, the requirements of the platform e-Códex aim at encouraging the development of two interdependent systems: the website and mobile application.

The website provides a digital platform that combines a core of services and interfaces that enable the sharing of information. This website implements functions of registration of digital content, including its metadata, the definition of trails (content in shackles) and a web service that will provide services of data consumption from the list of content/metadata, which will be presented by the mobile application.

The web service is a solution that makes it possible that different types of applications, running on many platforms and operating systems, can interact and exchange information in a safe and transparent way. This web service will provide the link between the mobile application and the information stored on the website.

The module for mobile devices of e-Códex has as main objective to be the means by which the public will have access to all content produced and organized by the platform. The technology Adobe PhoneGap (2016) was used for the development of the mobile application. It is an open source distribution of the framework Apache Cordova (2015). This technology allows us to encode in a single language and from this code an application that runs on a specific platform can be generated, as Android, IoS and Windows Phone, without having to write native code for each of these platforms. The applications created with that technology are called hybrids, because they have a piece of code native to the platform and another part is web-based (HTML5, CSS3, and JavaScript). This approach allows an application to be developed with versions for several different platforms with less effort.

Figure 3 illustrates the main functionalities supported by the Web module and the mobile application (App). The application (App) has two blocks of functionalities referring to user's registration and access to the digital content available.

Among the features of the application, the entry point is a field of research (search). When the user engaging, the research from a typed text, it will be performed a search in metadata of all content. The results of a query will be displayed and the user will have the option to view them online or download them (for cases in which the user needs to access the content in such a way off-line). The application will also have an area in which it will be listed all content already 


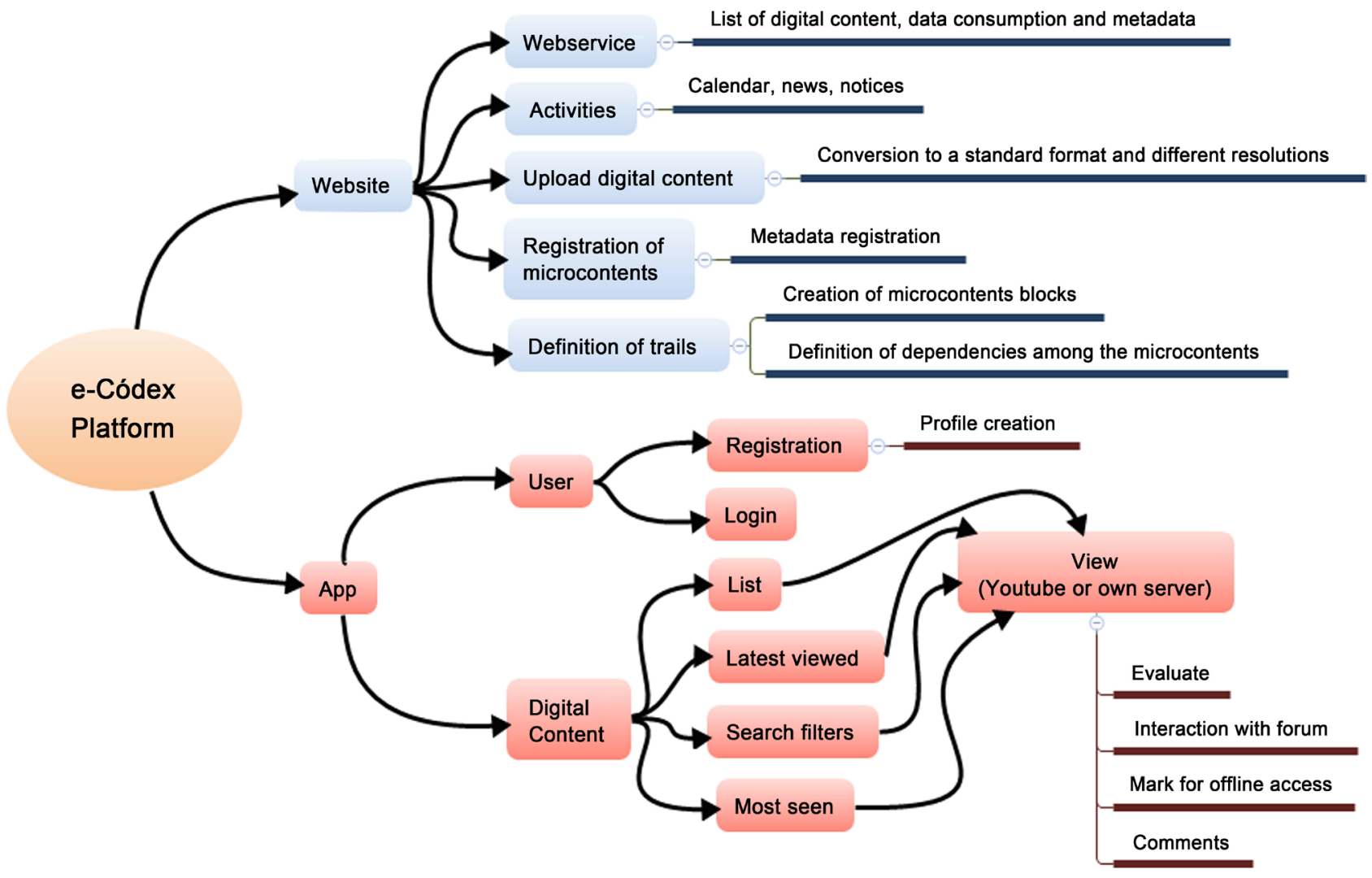

Figure 3. Architecture of the e-Códex Platform.

displayed by the user. In another area, there will be suggestions for content that are related to content that the user has already viewed. So that the user can stop the use and be able to return at any time, an important feature is to allow him to continue viewing content from the exact moment from where he stopped on the last access.

As a way to ensure that contents have a relationship of dependence, i.e., to watch the video B is required to have watched the video A, the application implements this restriction when there is this type of dependence between the content. Collaboration is encouraged in the application with the options of "like/ dislike", and comments for each content, and also from a forum that can be created and supplied by users to discussions about a particular content.

Figure 3 depicts the architecture for the platform e-Códex.

\section{Conclusion}

The construction of the platform e-Códex was mirrored on the perceptions and interests of interactors, properly analyzed and discussed in the light of the theoretical and conceptual ordinances, relating to the establishment of a virtual space facing the implementation of actions of educational and communicational, within the scope of the Project Forest Code. In this sense, the platform e-Códex incorporates important aspects revealed by interactors, as the need of its creation; its main characteristics and contributions; the possibilities of use; and, the forms of organization of content and activities offered. 
In turn, the digital technologies employed in the construction of this mobile platform were selected on the basis of minimum technical requirements able to promote interaction, collaboration, participation and sharing of information, knowledge, experiences, etc., usually applied to digital spaces educational and/or communicational.

Supported by the theoretical framework of education and in particular of cyberculture, with emphasis on aspects of ubiquity, pervasivity, hybridity, and multimodality of virtual spaces, the construction of the platform e-Códex is materialized as a technological tool to support the development of abilities which favour the interaction of individuals in the virtual environment.

\section{References}

Adobe PhoneGap (2016). Build Amazing Mobile Apps Powered by Open Web Tech: Create Your App with PhoneGap. San Jose, CA: Adobe PhoneGap. http://phonegap.com

Almeida, M. E. B., \& Valente, J. A. (2012). Integração currículo e tecnologias e a produção de narrativas digitais. Currículo sem Fronteiras, 12, 57-82.

http://goo.gl/z0oqTs

Alvarenga Neto, R. C. D., \& Barbosa, R. R. (2007). Práticas de gestão do conhecimento no contexto organizacional brasileiro: Rumo à gestão de contextos capacitantes. In Enancib, VIII Enancib-Encontro Nacional de Pesquisa em Ciência da Informação (19 p.). Salvador: Ibict. http://enancib.ibict.br/index.php/enancib/viiienancib/paper/viewFile/2891/2019

Alves, P. A. B. (2014). Características e usos das plataformas colaborativas no contexto da pesquisa científica: Proposta a pesquisadores da área ambiental (72 p.). São Paulo: USP/ECA.

http://grupo-ecausp.com/digicorp/wp-content/uploads/2015/05/Paulo-Andr\%C3\%A9Barros-Alves.pdf

Apache Cordova (2015). Mobile Apps with HTML, CSS \& JS: Target Multiple Platforms with One Code Base. Los Angeles, CA: Apache Cordova.

https://cordova.apache.org

Ayas, C. (2006). An Examination of the Relationship between the Integration of Technology into Social Studies and Constructivist Pedagogies. The Turkish Online Journal of Educational Technology-TOJET, 5, 14-24.

Backes, L. (2007). A formação do educador em mundos virtuais: Uma investigação sobre os processos de autonomia e de autoria. $186 \mathrm{f}$. Dissertação (Mestrado)-Programa de Pós-Graduação em Educação, São Leopoldo: Universidade do Vale do Rio dos Sinos-Unisinos.

Backes, L. (2011). A configuração do espaço de convivência digital virtual: A cultura emergente no processo de formação do educador. $362 \mathrm{f}$. Tese (Doutorado)-Programa de Programa de Pós-Graduação em Educação, Universidade do Vale do Rio dos Sinos-Unisinos, São Leopoldo: Co-tutela em Science de l'Education, Université Lumière Lyon 2.

Backes, L. (2013). Hibridismo tecnológico digital: Configuração dos espaços digitais virtuais de convivência. LE@D, out. Unpaged.

https://repositorioaberto.uab.pt/bitstream/10400.2/3050/1/bridridismo.pdf

Baldwin, C. Y., \& Woodard, J. (2008). The Architecture of Platforms: A Unified View (31 p.). Boston, MA: Harvard Business School. 
http://www.hbs.edu/faculty/Publication\%20Files/09-034_149607b7-2b95-4316-b4b6-1 df66dd34e83.pdf https://doi.org/10.2139/ssrn.1265155

Bozal, M. G. (2006). Escala mixta Likert-Thurstone. Anduli-Revista Andaluza de Ciencias Sociales, No. 5, 81-95. http://institucional.us.es/revistas/anduli/5/art_6.pdf

Brasil (2012). Lei $n^{\circ} 12.651$, de 25 de maio de 2012. Dispõe sobre a proteção vegetal nativa [...]. Brasília: Câmara dos Deputados.

Caetano Nêto, J. (2009). Dispositivos móveis e estética tecnológica: O espaço e a construção narrativa. 105 p. Dissertação (Mestrado-Tecnologia da Inteligência e Design Digital), São Paulo: Pontifícia Universidade Católica de São Paulo.

Caetano Nêto, J. (2011). O espaço híbrido na construção narrativa. [São Paulo: ProCoa2011]. Projeto Circuito Outubro aberto, jul. 2011. Veículo \#3. R. http://www.ohassi.com.br/downloads/veiculoIII.pdf

Canclini, N. G. (2006). Culturas híbridas (4th ed.). São Paulo: Edusp.

Carvalho, J. R. P., Vieira, S. R., \& Moran, R. C. C. P. (2002). Analysis of Correspondence-A Useful Tool to Interpret Yield Mapping. The Revista Brasileira de Ciência do Solo, 26, 435-443. http://www.scielo.br/pdf/rbcs/v26n2/17.pdf

Castro, C. H. S., \& Ribeiro, A. E. (2010). Interação para emergência de comunidades virtuais de aprendizagem. Hipertextus, Revista Digital, No. 5, 12 p.

http://www.hipertextus.net/volume5/Carlos-Henrique-De-Castro-\&-Ana-Elisa\%20Rib eiro.pdf

Choo, C. W. (1996). The Knowing Organization: How Organizations Use Information to Construct Meaning, Create Knowledge and Make Decisions. International Journal of Information Management, 16, 329-340.

http://ac.els-cdn.com/0268401296000205/1-s2.0-0268401296000205-main.pdf?_tid=e9 3f3fe6-9b78-11e6-9c17-00000aacb35e\&acdnat=1477485609_5eef6294e10cd3b37d40623 $\underline{86 \mathrm{a} 1063 \mathrm{~b} 4}$ https://doi.org/10.1016/0268-4012(96)00020-5

Coll, C., Bustos, A., \& Engel, A. (2010). As comunidades virtuais de aprendizagem. In C. Coll, \& C. Monereo (Eds.), Psicologia da educação virtual: Aprender e ensinar com as tecnologias da informação e comunicação (pp. 268-286). Porto Alegre: Artmed.

Conforto, E. C., Amaral, D. C., \& Silva, L. (2011). Roteiro para revisão bibliográfica sistemática: Aplicação no desenvolvimento de productos e gerenciamento de projetos. In Instituto de Gestão de Desenvolvimento do Produto, Congresso Brasileiro de Gestão de Desenvolvimento de Produto-CBGDP(12 p.). Porto Alegre: IBGDP.

Cunha Jr., M. V. (2000). M. Análise multidimensional de dados categóricos: Aplicação das análises de correspondência em marketing e sua integração com técnicas de análise de dados quantitativos. Revista de Administração, 35, 32-50.

da Silva, S. (2010). Redes sociais digitais e educação. Revista Iluminart, No. 5, 36-46. https://petbio.icb.ufg.br/up/317/o/volume1numero5artigo4.pdf?1351211156

Embrapa (2011). Deliberação no 23, de 28 de fevereiro de 2011. Boletim de Comunicações Administrativas, 37, 61-72.

Embrapa (2014). VI Plano diretor da Embrapa: 2014-2034 (28 p.). Brasília: Embrapa.

Embrapa Agricultural Informatics (2016). Embrapa Agricultural Informatics- Portal Embrapa.

https://www.embrapa.br/group/intranet/embrapa-informatica-agropecuaria

Evers, H.-D. (2002). Towards a Malaysian Knowledge Society. In III International Malaysian Studies Conference (23 p.). Bonn: Center for Development Research. 
Freitas, S., \& Neumann, T. (2009). The Use of "Exploratory Learning" for Supporting Immersive Learning in Virtual Environments. Computers \& Education, 52, 343-352. https://doi.org/10.1016/j.compedu.2008.09.010

Jones, P. M. (2001). Collaborative Knowledge Management, Social Networks, and Organizational Learning. https://human-factors.arc.nasa.gov/publications/collab_know_paper.pdf

Kress, F., \& Van Leueen, T. (2001). Multimodal Discourse: The Modes and Media of Contemporary Communication. London: Edward Arnold.

Kuhlen, R. (2003). Change of Paradigm in Knowledge Management: Framework for the Collaborative Production and Exchange of Knowledge. In H. C. Hobohm (Eds.), Word Library and Information Congress: 69th IFLA General Conference and Council (pp. 21-38). De Gruyter Saur.

http://www.kuhlen.name/MATERIALIEN/Vortraege03-Web/rk_ifla03_for_publ30080 3.pdf

Lastres, H. M. M. (1994). Acesso à informação: Estratégia para competitividade. Ciência da Informação, 23, 287-288.

http://revista.ibict.br/ciinf/article/view/560/0

Latour, B. (1994). Jamais fomos modernos. São Paulo: Editora 34.

Lemos, A. (2007). Mídia locativa e território informacional. In P. Arantes, \& L. Santaella (Eds.), Estéticas tecnológicas (25 p.). São Paulo: PUC-SP.

Maffesoli, M. (1996). No fundo das aparências. Petrópolis: Vozes.

Martin, F., \& Parker, M. A. (2014). Use of Synchronous Virtual Classrooms: Why, Who, and How? Journal of Online Learning and Teaching, 10, 192-210.

http://jolt.merlot.org/vol10no2/martin_0614.pdf

Mattar, J. (2011). Web 2.0 e redes sociais na educação à distância: Cases no Brasil. La educ@ción Revista digital, (145), mayo.

http://www.educoea.org/portal/La_Educacion_Digital/145/studies/EyEP_mattar_ES.pd f

Mayes, T., \& Freitas, S. (2004). Review of E-Learning Theories, Frameworks and Models (43 p.). London: Joint Information Systems Committee.

https://goo.gl/sEjJfG

Nonaka, I, \& Konno, N. (1998). The Concept of "Ba": Building a Foundation for Knowledge Creation. California Management Review, 40, 40-54.

http://home.business.utah.edu/actme/7410/Nonaka\%201998.pdf https://doi.org/10.2307/41165942

Portal Brasil (2012). Entenda as principais regras do Código Florestal. Brasília: Presidência da República.

http://www.brasil.gov.br/meio-ambiente/2012/11/entenda-as-principais-regras-do-codi go-florestal

Primo, A. (2003). Quão interativo é o hipertexto? Da interface potencial à escrita coletiva. Fronteiras: Estudos Midiáticos, 5, 125-142.

Rebollo-Catalán, A., \& Vico-Bosch, A. (2014). El apoyo social percibido como factor de la inclusión digital de las mujeres de entorno rural en las redes sociales virtuales. Comunicar, 43, 173-180. https://doi.org/10.3916/C43-2014-17

Recuero, R. C. (2000). A Internet e a nova revolução na comunicação mundial. http://www.raquelrecuero.com/revolucao.htm

Santaella, L. (2009). Matrizes da linguagem e pensamento: Sonora, visual e verbal: Aplicações na hipermídia (3rd ed.). São Paulo. 
Santaella, L. (2010). Culturas e artes do pós-humano: Da cultura das mídias à cibercultura (4th ed., 357 p.). São Paulo: Paulus.

Santaella, L. (2011a). Linguagens líquidas na era da mobilidade (2nd ed., 468 p.). São Paulo: Paulus. (Comunicação)

Santaella, L. (2011b). Navegar no ciberespaço: O perfil cognitivo do leitor imersivo (4th ed., 191 p.). São Paulo: Paulus.

Santaella, L., \& Lemos, R. (2010). Redes sociais digitais: A cognição conectiva do twitter (137 p.). São Paulo: Paulus. (Comunicação)

Santos, M. (1980). Por uma geografia nova: Da crítica da geografia a uma geografia crítica. São Paulo: Hucitec.

SAS Institute Inc. (2008). SAS/STAT 9.2 users's guide. Cary, NC: SAS Institute Inc.

Sheller, M., \& Urry, J. (2006). Mobile Technologies and the City. London: Routledge.

Spagnoletti, P., Resca, A., \& Lee, G. (2015). A Design Theory for Digital Platforms Supporting Online Communities: A Multiple Case Study. Journal Information Technology, 30, 364-380. https://doi.org/10.1057/jit.2014.37

Tönnies, F. (1955). Community and Association: (Gemeinschaft und Gesellschaft). London: Routledge \& Kegan Paul.

Torres, T. Z., \& Amaral, S. F. (2011). Aprendizagem colaborativa e web 2.0: Proposta de modelo de organização de conteúdos interativos. ETD-Educação Temática Digital, 12, 49-72.

http://www.brapci.ufpr.br/brapci/index.php/article/download/16094

Torres, T. Z., Souza, M. I. F., Carvalho, J. R. P., \& Evangelista, S. R. M. (2015). Multimedia Design and Transmedia Storytelling: Content Production for Microtrainings. Creative Education, 6, 2466-2480. https://doi.org/10.4236/ce.2015.623254

Submit or recommend next manuscript to SCIRP and we will provide best service for you:

Accepting pre-submission inquiries through Email, Facebook, LinkedIn, Twitter, etc. A wide selection of journals (inclusive of 9 subjects, more than 200 journals)

Providing 24-hour high-quality service

User-friendly online submission system

Fair and swift peer-review system

Efficient typesetting and proofreading procedure

Display of the result of downloads and visits, as well as the number of cited articles

Maximum dissemination of your research work

Submit your manuscript at: http://papersubmission.scirp.org/

Or contact ce@scirp.org 